Vol. XXIII. APRIL, $1920 . \quad$ No. 266.

ABSTRACTS FROM THE ORIGINAL PAPERS.

\title{
ON THE ESSENTIAL OIL OF PERYLLA NANKINENSIS DCNE.
}

By Seiji Furukawa, Nögakushi and Zenjirō Tomizawa.

[Received March 5, 1920.]

The authors studied the formation, distribution, transformation, as well as the chemical composition of the essential oil of Perylla Nankinensis, Dene, at different stages of cultivation. The chief results obtained may be summarised as follows :--

I. The essential oil and its mother substance (glucoside) are form only in the leaves. The former is then transported to the ears and radiates from the sepals.

2. The essential oil and its mother substance gradually accumulate in the leaves until the ears appear. From then on the total amount of oil and glucoside remains nearly constant until the beginning of flowering time, but the action of enzymes, thus producing the essential oil which chiefly consists of Perylla aldehyde.

3. The radiation of the perfume from the sepals is most active during the flowering time, though it continues even after that.

4. With the appearance of ears the glucoside in the leaves begins to decompose and entirely disappears after flowering.

5. For the distillation of the oil, the plant must therefore be harvested soon after the ears appear or, at the latest, in the beginning of flowering time. In order to convert the glucoside into oil, the gathered plants must be dried at low temperature, because too high temperature 
destroys the enzyme action, causes resinifying and consequently decrease of solubility of the oil.

6. When frish plants are subjected to distillation, at different stages of growth, the oils obtained show a gradual increase in aldehyde and decrease in ester until the end of the flowering time. But the oils obtained from dried plants contain less aldehyde and more ester and alcohol at the end of the flowering time than at the beginning.

7. The oil from dried leaves contains more aldehyde and less ester than that from the ears. The alcohol content is nearly the same in both oils until the beginning of the flowering time, but afterwards it becomes higher in the oil of ears.

8. The solubitity of the oils gradually decreases with the growth of the

- plants. This is especially the case with dried plants. The oil from leaves always shows greater solubility than that of ears.

9. The leaves, ears and especially sepals are richest in oil. Stems are poorer, while seeds and roots are quite free of it.

10. From various samples of the essential oil were isolated :20-30\% 1-'imonen, 44-57\% perylla aldehyde, beside a little $\alpha$-pinen. The following derivatives of perylla aldehyde were also prepared by the authors, i.e. :-

a) Perylla aldehyde $\mathrm{C}_{10} \mathrm{H}_{14} \mathrm{O}:$ B.p. $237^{\circ} \mathrm{C} \cdot \mathrm{D}_{16}=0.9675[\alpha]_{10}^{200}=-145^{\circ} .8$

b) $\alpha$-anti-aldoxim of the aldehyde $\mathrm{C}_{9} \mathrm{H}_{13} \mathrm{CH}$.; m.p. ${ }_{102}{ }^{\circ} \mathrm{C}$.

$$
\mathrm{HO}-\stackrel{\|}{\mathrm{N}}
$$

Colorless crystals possessing a strong sweet taste, i.e. nearly 2000 times that of sugar, or 4-8 times that of saccharine.

c) Hydrochlorate of $\alpha$-anti-oxim $\mathrm{C}_{9} \mathrm{H}_{13} \mathrm{CH} \cdot \mathrm{NOH} \cdot \mathrm{HCl}: \mathrm{m} . \mathrm{p} . \mathrm{II}_{4}{ }^{\circ} \mathrm{C}$. unstable white crystals.

d) $\beta$-syn-a!doxim $\mathrm{C}_{9} \mathrm{H}_{13} \mathrm{CH}$ : m.p. $129^{\circ}$. colorless triclinic prisms, not sweet. $\stackrel{\|}{\mathrm{N}}-\mathrm{OH}$

e) Sodium salt of $\alpha$-anti-oxim; white cryslals, easily decomposed to $\mathrm{NaOH}$ and $\alpha$-anti-oxim.

f) Nitril of peryllic acid $\mathrm{C}_{9} \mathrm{H}_{13} \mathrm{CN}:$ B.p. $._{15} \quad 123^{\circ} \mathrm{C}, \mathrm{D}_{15}=0.9490-0.9488$ nearly half as sweet as saccharine. 
g) Amido derivative of peryllic acid $\mathrm{C}_{3} \mathrm{H}_{13} \mathrm{CONH}_{2}:$ m.p. $16+165^{\circ}$ white crystals.

h) Peryllic acid $\mathrm{C}_{9} \mathrm{H}_{13} \mathrm{COOH}:$ m.p. $132-\mathrm{I} 33^{\circ}$. colorless pl ite.

i) Phenylhydrazone of the aldehyde $\mathrm{C}_{10} \mathrm{H}_{14}: \mathrm{N} \cdot \mathrm{NH} \mathrm{C}_{6} \mathrm{H}_{5}$ : needle with silky lustre, m.p. $107^{\circ} 5$.

j) Semicarbazone $\mathrm{C}_{10} \mathrm{H}_{14}: \mathrm{N} \cdot \mathrm{NH} \mathrm{CONH} \mathrm{C}_{2}$ : white crystals, m.p. 198-199.

k) Acetic ester of Perylla alcohol $\mathrm{C}_{9} \mathrm{H}_{13} \mathrm{CH}_{2} \mathrm{OOCCH}_{3}$ : B.p.13 $123-124^{\circ} \mathrm{C}$, $\mathrm{D}_{15}=0.9800$.

l) Perylla alcohol $\mathrm{C}_{9} \mathrm{H}_{1: 3} \mathrm{CH}_{2} \mathrm{OH}:$ B.p. $\cdot 11$ II $8-121^{\circ} \mathrm{C}, \mathrm{D}_{10}=0.9590$.

\section{SYNTHESIS OF INDIGO AND 6-6'-DIMETHYLINDIGO.}

\section{By Takeshi Shibata, Rigakushi.}

[Received March 5, 1920.]

The author obtained sodium salt of phenylglycin by a different method from that of Heumann. This sodium salt has been subjected to amide fusion and a maximum yield of $75 \%$ has been obtained after several experiments. The methods, on which the author proceeded, are represented in the following equations :

1. $\mathrm{ClCH}_{2} \mathrm{COOH}+\mathrm{C}_{2} \mathrm{H}_{5} \mathrm{OH}=\mathrm{ClCH}_{2} \mathrm{COOC}_{2} \mathrm{H}_{5}+\mathrm{H}_{2} \mathrm{O}$,

2. $\mathrm{ClCH}_{2} \mathrm{COOC}_{2} \mathrm{H}_{5}+2 \mathrm{C}_{6} \mathrm{H}_{5} \mathrm{NH}_{2}=\mathrm{C}_{6} \mathrm{H}_{5} \cdot \mathrm{NHCH}_{2} \mathrm{COOC}_{2} \mathrm{H}_{6}+\mathrm{C}_{6} \mathrm{H}_{5} \cdot \mathrm{NH}_{2} \cdot \mathrm{HCl}$,

3. $\mathrm{C}_{6} \mathrm{H}_{5} \cdot \mathrm{NIICH}_{2} \mathrm{COOC}_{2} \mathrm{H}_{5}+\mathrm{NaOH}=\mathrm{C}_{6} \mathrm{H}_{5} \mathrm{NHCH}_{2} \mathrm{COONa}+\mathrm{C}_{2} \mathrm{H}_{5} \mathrm{OH}$.

4. $\mathrm{C}_{6} \mathrm{II}_{5} \cdot \mathrm{NHCH}_{2} \mathrm{COONa}+\mathrm{NaNH}_{2}=\mathrm{C}_{6} \mathrm{H}_{4}\left\langle\mathrm{CO}_{\mathrm{CH}}^{\mathrm{NH}}\right\rangle \mathrm{CH}_{2}+\mathrm{NH}_{3}+\mathrm{Na}_{2} \mathrm{O}$.

5. $2 \mathrm{C}_{6} \mathrm{H}_{4}\left\langle{ }_{\mathrm{CO}}^{\mathrm{NH}}\right\rangle \mathrm{CH}_{2}+2 \mathrm{O}=\mathrm{C}_{6} \mathrm{H}_{4}\left\langle{ }_{\mathrm{CO}}{ }_{\mathrm{NH}}^{\mathrm{NH}}{ }_{\mathrm{C}} \mathrm{C}\left\langle{ }_{\mathrm{CO}}^{\mathrm{NH}}>\mathrm{C}_{6} \mathrm{H}_{4}+2 \mathrm{H}_{2} \mathrm{O}\right.\right.$.

In the amide fusion an addition of ethylester of phenylglycin is said to give the best yield and after several trials it may be concluded that the following proportion of the substances should be most favorable:

Sodium salt

Sodamide

Ester
28 Parts

35 "

7 , 
The presence of ester may probably lower the fusing temperature of the mixture and it reacts with soda, which is produced during fusion, we believe that this may result in the formation of indigo.

The estimation of indigo is carried out by the Rawsen method, according to which the author obtained $98.2 \%$ indigotin.

Synthesis of 6-6'-Dimethylindigo.

The author prepared 6-6'-dimethylindigo by the method analogous to that of synthesis of indigo described above. By the fusion of toylglycin sodium salt, 6-6'-dimethylindigo was easily formed as well as in the case of indigo. The reactions are represented as follows:
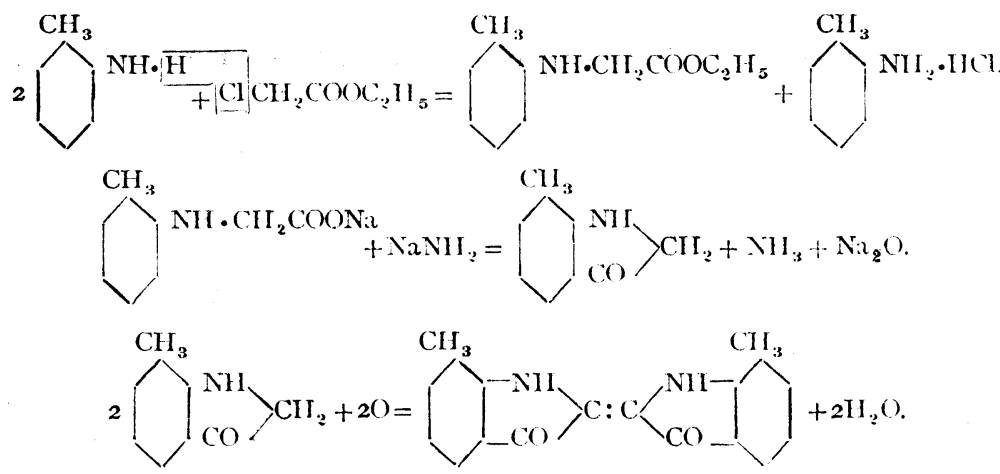

On the opinion of the author, the other two dimethyl-indigo could be prepared by the analogous method in employing m-toluidine or $p$-toluidinte in the place of o-toluidine in the process described above.

(9. 2. 20) 